\title{
ASSESSMENT OF MICRONUTRIENT EXTRACTANTS FROM SOILS OF PARANÁ, BRAZIL ${ }^{(1)}$
}

\author{
Marcos Vinicius Mansano Sarto ${ }^{(2)}$, Fábio Steiner ${ }^{(3)} \&$ Maria do \\ Carmo Lana ${ }^{(2)}$
}

\begin{abstract}
SUMMARY
In Brazil, plant-available micronutrients in the soil can be determined by several chemical extractants, the most common of which are dilute acid and chelating solutions. The purpose of this study was to assess the extractants $0.1 \mathrm{~mol} \mathrm{~L}^{-1} \mathrm{HCl}$, Mehlich-1, Mehlich-3 and DTPA for analysis of the micronutrients $\mathrm{Cu}, \mathrm{Zn}, \mathrm{Fe}$, and Mn in soils from the state of Paraná. In samples from 12 soils (0-20 cm layer), wheat was planted (Triticum aestivum), grown for 42 days after emergence, and then bean (Phaseolus vulgaris) for 38 days. At the end of each planting period, the soil was sampled again. All extractants tested to assess the availability of $\mathrm{Cu}, \mathrm{Zn}$, $\mathrm{Fe}$, and Mn correlated with each other. The efficiency of the extractants $\mathrm{HCl}$, Mehlich-3 and DTPA in assessing plant-available $\mathrm{Cu}$ was similar, unlike Mehlich-1, which proved less efficient. The extractants $\mathrm{HCl}$, Mehlich-1 and Mehlich-3 were less efficient in estimating plant-available $\mathrm{Zn}$ and $\mathrm{Fe}$, and the most indicated extractant is DTPA. The efficiency of the extractants HCl, Mehlich-1, Mehlich-3 and DTPA in assessing plant-available Mn in soils from Paraná was similar.
\end{abstract}

Index terms: soil analysis, correlation, copper, zinc, iron, manganese.

(1) Part of the Work for Completion Course in Agronomy of first author. Received for publication in December 10, 2010 and approved in July 22, 2011.

(2) Center of Agricultural Sciences, West Paraná State University, CEP 85960-000 Marechal Cândido Rondon (PR), Brazil. E-mail: marcos_sarto@hotmail.com, mclana@unioeste.br

(3) Department of Crop Science, College of Agricultural Sciences, São Paulo State University, CEP 18610-307 Botucatu (SP), Brazil. E-mail: fsteiner@fca.unesp.br 


\title{
RESUMO: AVALIAÇÃO DE EXTRATORES DE MICRONUTRIENTES EM SOLOS DO PARANÁ
}

\begin{abstract}
No Brasil, diversos extratores químicos são utilizados na determinação de micronutriente disponível para as plantas, destacando-se soluções ácidas diluídas e quelatantes. Neste trabalho, objetivou-se avaliar os extratores $\mathrm{HCl}$ 0,1 mol L-1, Mehlich-1, Mehlich-3 e DTPA, para análise dos micronutrientes $\mathrm{Cu}, \mathrm{Zn}$, Fe e Mn em solos do Estado do Paraná. Amostras de 12 solos coletadas da camada de $0-20 \mathrm{~cm}$ de profundidade foram cultivadas com plantas de trigo (Triticum aestivum) por 42 dias e, em sequência, com plantas de feijão (Phaseolus vulgaris) por 38 dias após a emergência. No final de cada cultivo foram coletadas amostras do solo. Todos os extratores testados para avaliar a disponibilidade de $\mathrm{Cu}, \mathrm{Zn}$, Fe e Mn correlacionaram entre si. Os extratores $\mathrm{HCl}$, Mehlich-3 e DTPA apresentaram eficiência semelhante na avaliação da disponibilidade de $\mathrm{Cu}$ às plantas, já o Mehlich-1 foi menos eficiente em estimar a disponibilidade desse elemento. Os extratores $\mathrm{HCl}$, Mehlich-1 e Mehlich-3 foram menos eficientes para estimar a disponibilidade de Zn e Fe para as plantas, sendo o DTPA o extrator mais indicado para tal. Os extratores HCl, Mehlich-1, Mehlich-3 e DTPA mostraram eficiência semelhante na avaliação da disponibilidade de Mn para as plantas em solos do Paraná.
\end{abstract}

Termos de indexação: análise do solo, correlação, cobre, zinco, ferro, manganês.

\section{INTRODUCTION}

Crop yields may be limited by micronutrient deficiency caused by the low natural fertility of some soils, considerable nutrient removal by harvests and excessive application of phosphate fertilizers and substances for correction of soil acidity, causing the insolubility of micronutrients in the soil (Bortolon \& Gianello, 2009).

Knowledge of micronutrient availability in the soil is fundamental for suitable fertilization recommendations, to avoid deficiency or toxicity problems. For the choice of a method for soil analysis, a positive correlation between the nutrient concentration determined by the method and the nutrient quantity taken up by plants is fundamental (Lopes \& Abreu, 2000).

Several methods for micronutrient assessment in soils are available, and many of the extractants in routine analyses are used for multiple elements, in general developed for other nutrients and used for determination of $\mathrm{Cu}, \mathrm{Zn}, \mathrm{Fe}$, and $\mathrm{Mn}$ due to the operational ease in laboratories for routine soil testing. However, the lack of standardization of extraction methods can affect the reliability of the analytical results, since the success of this practice is associated with the choice of an extractant suited for the specific agricultural conditions in the region under study.

In Brazil, different chemical extractants are used to determine plant-available $\mathrm{Cu}, \mathrm{Zn}, \mathrm{Fe}$, and $\mathrm{Mn}$, particularly with dilute acid solutions, e.g, $0.1 \mathrm{~mol} \mathrm{~L}^{-1}$ HCl (Wear \& Sommer, 1948) and Mehlich-1 $\left(0.05 \mathrm{~mol} \mathrm{~L}^{-1} \mathrm{HCl}\right.$ and $\left.0.0125 \mathrm{~mol} \mathrm{~L}^{-1} \mathrm{H}_{2} \mathrm{SO}_{4}\right)$ (Mehlich, 1953), and the chelates, such as DTPA and EDTA (Lindsay \& Norvell, 1978). The extraction principles of the methods vary greatly. Acid extractants are based on lowering the $\mathrm{pH}$ and the consequent solubilization of some compounds containing these elements. Chelating extractants in turn, have the capacity of reducing the activity of dissolved metals., resulting in release of more soluble compounds in buffered pH (Motta et al., 2007).

The selection of an extractant to determine the availability of an element in the soil is based on the standard extractant: the plant. For this reason, Silva et al. (2003) verified that the quantity of $\mathrm{Cu}$ and $\mathrm{Zn}$ accumulated in soybean plants in different soils of the State of Paraná correlated better with the content recovered by Mehlich-3 than by Mehlich-1 and DTPA. Menezes et al. (2010) observed that the quantity of Zn taken up by maize plants in different limed and unlimed soils of Minas Gerais was significantly correlated with the contents recovered by the extractants Mehlich-1, Mehlich-3 and DTPA. On the other hand, Bortolon \& Gianello (2009) observed that 0.1 mol L-1 $\mathrm{HCl}$, Mehlich-1 and Mehlich-3 did not adequately assess $\mathrm{Cu}$ and $\mathrm{Zn}$ availability for maize and soybean plants in soils of the state of Rio Grande do Sul. Similarly, Fonseca et al. (2010) concluded that the extractants $\mathrm{HCl}$, Mehlich-1, Mehlich-3 and DTPA were ineffective in predicting availability of cation micronutrients for wheat after soil surface liming in Ponta Grossa (PR). These contradictory results call for a greater number of studies, as well as more in-depth interpretations, to better predict micronutrient availability and plant response.

The low number of studies regarding methods for assessment of micronutrient availability for the state of Paraná, makes a definition of the most adequate method for the soil conditions of the state more difficult. Due to this lack of studies on correlation and 
calibration, there is no official classification regarding the availability values for interpretation and recommendation of fertilization for the state of Paraná. Thus, research that relates the quantities extracted by different extractants and accumulated by plants is of fundamental importance.

The purpose of this study was to assess the extractants $0.1 \mathrm{~mol} \mathrm{~L}^{-1} \mathrm{HCl}$, Mehlich-1, Mehlich-3 and DTPA for analysis of the micronutrients $\mathrm{Cu}, \mathrm{Zn}, \mathrm{Fe}$, and Mn in soils of the state of Paraná.

\section{MATERIAL AND METHODS}

The experiment was carried out in an experimental greenhouse of the Universidade Estadual do Oeste do Paraná (West Paraná State University) UNIOESTE, in Marechal Cândido Rondon, PR. Soil from the 0-20 cm layer was sampled at 12 locations in Paraná (PR), in distinct regions and properties (Table 1). The soils were classified in accordance with Embrapa (2006) and the chemical and granulometric analyses according to the methodology of Embrapa (1997).

Dolomitic lime $(\mathrm{CaO}=25 \%, \mathrm{MgO}=12 \%$ and effective calcium carbonate equivalent $=95 \%$ ) was used to correct soil acidity, and the need for soil correction was defined according to the base saturation method (Raij et al., 1997) to increase base saturation to $70 \%$ for clayey soils, $50 \%$ for sandy soils and $60 \%$ for medium texture soils. The soils were then moistened to $80 \%$ of the water retention capacity and incubated for 25 days. The range of base saturation was 55-74\%, of $\mathrm{pH}$ in $\mathrm{CaCl} 25.6-6.4$ and of organic matter $7-32 \mathrm{~g} \mathrm{dm}^{-3}$. The soils were fertilized with $80 \mathrm{mg} \mathrm{dm}^{-3} \mathrm{~N}$ (as ammonium nitrate), $120 \mathrm{mg} \mathrm{dm}^{-3}$
$\mathrm{P}$ (triple superphosphate), $100 \mathrm{mg} \mathrm{dm}^{-3} \mathrm{~K}$ (potassium chloride), $15 \mathrm{mg} \mathrm{dm}-3 \mathrm{~S}$ (calcium sulfate), $1 \mathrm{mg} \mathrm{dm}^{-3}$ Mo (ammonium molybdate) and $2 \mathrm{mg} \mathrm{dm}^{-3} \mathrm{~B}$ (boric acid). Then $7 \mathrm{dm}^{3}$ of each soil sample was transferred to $8 \mathrm{dm}^{3}$ polyethylene pots.

The greenhouse experiment consisted of two plantings: first - wheat (Triticum aestivum L., cultivar CD 208) and the second - common bean (Phaseolus vulgaris L., cultivar IPR 81). The treatments represented by 12 soils were arranged in a randomized block design with four replications.

In both growing seasons, $\mathrm{N}$ (ammonium nitrate) was sidedressed (40 $\mathrm{mg} \mathrm{dm}^{-3}, 10$ and 20 days after plant emergence). The soil water content was monitored daily and corrected whenever necessary to near $80 \%$ of the water retention capacity.

Before planting wheat and bean, soil samples were collected from the 0-20 cm layer using a bucket auger (diameter $25 \mathrm{~mm}$ ). The samples were dried in a forcedair oven for $72 \mathrm{~h}$ at $45 \pm 2{ }^{\circ} \mathrm{C}$ and the soil was ground, passed through a $2 \mathrm{~mm}$ mesh sieve and stored for later analysis.

Wheat and bean was harvested 42 and 38 days after emergence, respectively. The above ground plant part was cut at the level of the soil surface, dried in a forced air oven at $65 \pm 2{ }^{\circ} \mathrm{C}$ for $72 \mathrm{~h}$, weighed and then ground in a Wiley mill. The $\mathrm{Cu}, \mathrm{Zn}, \mathrm{Fe}$, and $\mathrm{Mn}$ contents in the plant matter were determined by nitricperchloric digestion, and the contents in the extracts by atomic absorption spectrophotometry with flame atomization (Malavolta et al., 1997). The micronutrient plant uptake was calculated from the dry matter weight per pot and the respective dry matter contents.

The $\mathrm{Cu}, \mathrm{Zn}$ Fe and Mn soil-available contents were extracted by the solutions $0.1 \mathrm{~mol} \mathrm{~L}^{-1} \mathrm{HCl}$ (Tedesco

Table 1. Classification, sampling sites and physical and chemical properties of soils used in the experiment

\begin{tabular}{|c|c|c|c|c|c|c|c|}
\hline Description $^{(1)}$ & Class $^{(1)}$ & Location & Clay & $\mathrm{pH} \mathrm{CaCl}_{2}$ & $\begin{array}{c}\text { Organic } \\
\text { matter }\end{array}$ & CEC & V \\
\hline & & & $\mathrm{g} \mathrm{kg}^{-1}$ & & $\mathrm{~g} \mathrm{dm} \mathrm{m}^{-3}$ & $\mathrm{cmol}_{\mathrm{c}} \mathrm{dm}^{-3}$ & $\%$ \\
\hline 1. Latossolo Vermelho eutroférrico & LVef & Mal. Cândido Rondon & 900 & 5.8 & 21 & 15.2 & 65 \\
\hline 2. Latossolo Vermelho distrófico & $\mathrm{LVd}$ & Ponta Grossa & 785 & 5.9 & 18 & 14.3 & 67 \\
\hline 3. Latossolo Vermelho Amarelo eutrófico & LVAe & Umuarama & 250 & 6.0 & 16 & 13.1 & 64 \\
\hline 4. Latossolo Vermelho-Amarelo distrófico & LVAd & Ponta Grossa & 315 & 6.2 & 22 & 13.2 & 61 \\
\hline 5. Nitossolo Vermelho eutroférrico & NVef & Mal. Cândido Rondon & 550 & 6.0 & 25 & 15.9 & 66 \\
\hline 6. Nitossolo Vermelho eutrófico & $\mathrm{NVe}$ & Ponta Grossa & 785 & 5.9 & 32 & 16.5 & 65 \\
\hline 7. Argissolo Vermelho-Amarelo distrófico & PVAd & Umuarama & 85 & 6.4 & 7 & 6.9 & 55 \\
\hline 8. Argissolo Vermelho-Amarelo eutrófico & PVAe & Mercedes & 700 & 5.6 & 23 & 17.1 & 67 \\
\hline 9. Neossolo Regolítico eutrófico & $\mathrm{RRe}$ & Mal. Cândido Rondon & 635 & 5.8 & 12 & 15.5 & 66 \\
\hline 10. Plintossolo Háplico & $\mathrm{FX}$ & Ponta Grossa & 615 & 6.2 & 22 & 14.3 & 74 \\
\hline 11. Gleissolo Háplico & GX & Mal. Cândido Rondon & 450 & 5.6 & 17 & 17.7 & 71 \\
\hline 12. Cambissolo Háplico & $\mathrm{CX}$ & Ponta Grossa & 235 & 6.3 & 12 & 10.2 & 62 \\
\hline
\end{tabular}

\footnotetext{
(1) Brazilian Classification as proposed by Embrapa (2006).
} 
et al., 1995), Mehlich-1 (Tedesco et al., 1995), Mehlich3 (Tedesco et al., 1995) and DTPA (Büll \& Bertani, 2001). In all extracts, $\mathrm{Cu}, \mathrm{Zn}, \mathrm{Fe}$, and $\mathrm{Mn}$ was determined by atomic absorption spectrophotometry with flame atomization.

The micronutrient contents by the extractants HCl, Mehlich-1, Mehlich-3 and DTPA and the quantities accumulated in the above-ground part of wheat and bean plants were subjected to analysis of variance; the effect of the contents was partitioned for each extractant and crop by means of linear regression analysis. Correlation analyses were also established for the different extractants and among the contents extracted from the soils and the quantity accumulated in the plants. The predictive power for assessment of available micronutrients by the different extractants was determined mainly by the analysis of correlation coefficients.

\section{RESULTS AND DISCUSSION}

\section{Comparison of extractants}

The $\mathrm{Cu}, \mathrm{Zn}, \mathrm{Fe}$, and Mn contents extracted from the soil by Mehlich-1, the method adopted by laboratories in Paraná (PR), correlated significantly with the contents extracted by $\mathrm{HCl} 0.1 \mathrm{~mol}^{-1}$, Mehlich3 and DTPA (Table 2). These results indicate that regardless of the nature of the extractant, acid or chelating, the extraction capacity of all methods studied is similar for quantifying $\mathrm{Cu}, \mathrm{Zn}, \mathrm{Fe}$, and $\mathrm{Mn}$ contents in PR soils, which are highly variable in chemical, physical and mineralogical properties. Thus, due to the greater ease of operation in laboratories for routine soil testing, Mehlich-1 is the most indicated extractant for combined extractions of the studied micronutrients.

In studies by Bataglia \& Raij (1989), Ferreira \& Cruz (1992) and Bataglia \& Raij (1994) with soils from the state of São Paulo, the efficiency of the acid and chelating extractants to determine soil micronutrients was the same. In a sandy PR soil, Ortiz et al. (2007) also found significant correlations between Mehlich-1 and DTPA. However, Muraoka et al. (1983) observed superiority of EDTA and DTPA over $0.1 \mathrm{~mol} \mathrm{~L}^{-1} \mathrm{HCl}$. Abreu \& Raij (1996) even stated that DTPA was most efficient in assessing the changes in $\mathrm{Zn}$ availability in São Paulo soils, as a result of the $\mathrm{pH}$ change of the soil solution.

Correlation coefficients among the $\mathrm{Cu}, \mathrm{Zn}, \mathrm{Fe}$, and Mn contents of the soil extracted with Mehlich-1 and $\mathrm{HCl}$ ranged from $0.59(\mathrm{p}<0.05)$ to $0.88(\mathrm{p}<0.01)$ and from $0.67(p<0.01)$ to $0.93(p<0.01)$ for the first and second planting period, respectively (Table 2 ). The significant correlation between the soil-extracted micronutrient contents with Mehlich-1 and $0.1 \mathrm{~mol} \mathrm{~L}^{-1}$ $\mathrm{HCl}$ may be explained by the fact that the chemical extraction principle of these two procedures is the same. In a study of 26 soils from the state of São

Table 2. Correlation among the different extractants tested to assess $\mathrm{Cu}, \mathrm{Zn}$, Fe, and Mn availability in 12 soils of Paraná under wheat and common bean $(n=48)$

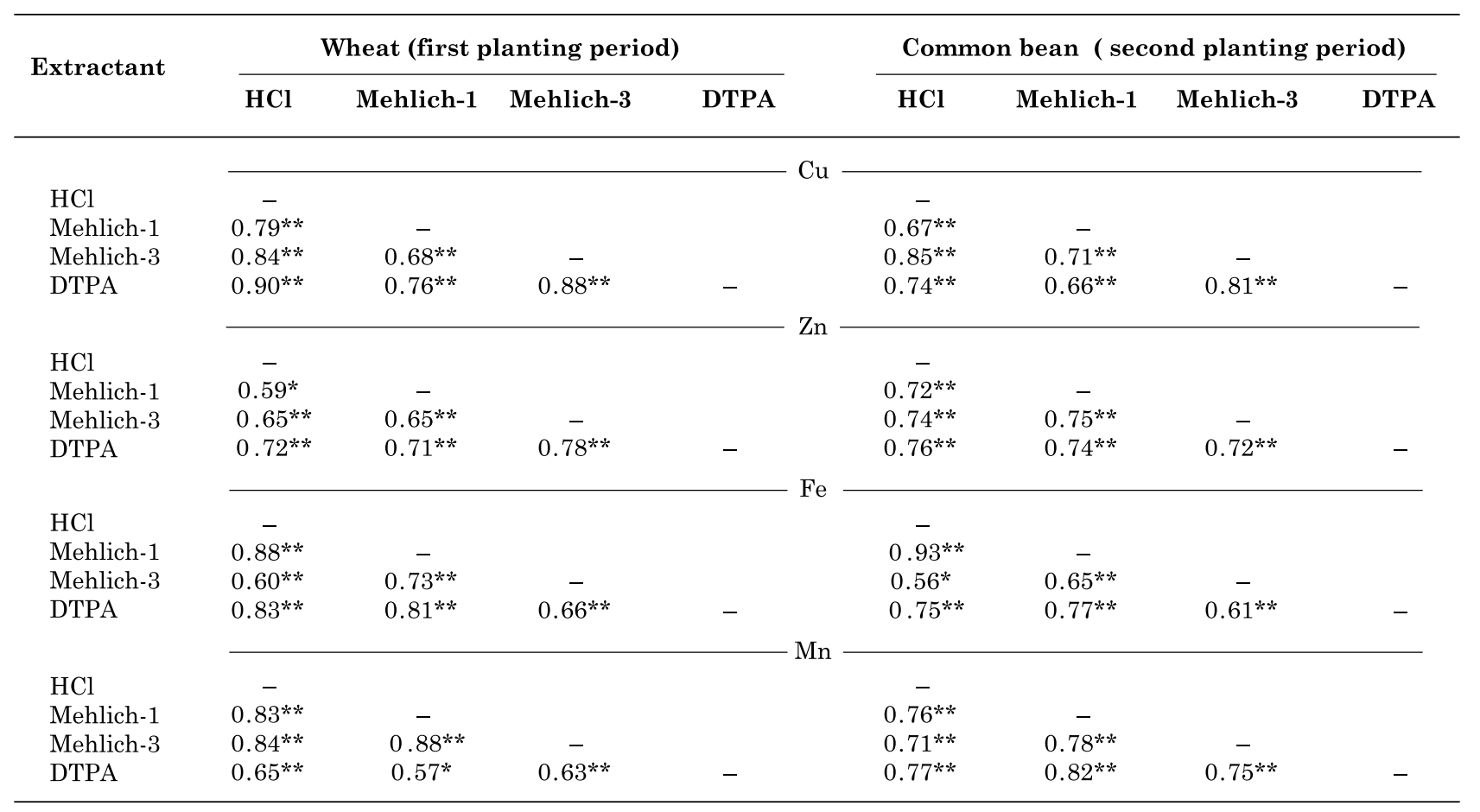


Paulo, Bataglia \& Raij (1994) obtained a high degree of association $(r=0.99 ; \mathrm{p}<0.01)$ between the $\mathrm{Zn}$ contents extracted by $\mathrm{HCl}$ and Mehlich-1. Pereira et al. (2001) compared these two extractants in 103 soil samples from the state of Rio de Janeiro and found a correlation coefficient of $0.75(\mathrm{p}<0.05)$ and the $\mathrm{Cu}$ contents extracted were approximately $25 \%$ lower than determined with Mehlich-1. In soils of the state of Rio Grande do Sul, Bortolon \& Gianello (2009) found correlation coefficients between the $\mathrm{Cu}$ and $\mathrm{Zn}$ contents extracted with Mehlich-1 and $\mathrm{HCl}$ of $0.92(\mathrm{p}<0.01)$ and $0.93(p<0.01)$ for maize and $0.63(p<0.01)$ and $0.97(\mathrm{p}<0.01)$ for soybean, respectively.

$\mathrm{Cu}$ content in the soil and accumulated in plants

Correlation coefficients between the $\mathrm{Cu}$ content extracted from the soil with $0.1 \mathrm{~mol} \mathrm{~L}^{-1} \mathrm{HCl}$ and the quantity of $\mathrm{Cu}$ accumulated in plants were 0.79 $(p<0.01)$ and $0.81(p<0.01)$ for the first and second planting, respectively (Figure 1a). In a similar study, with 12 soils from Rio Grande do Sul, Bortolon \& Gianello (2009) obtained similar coefficients between the $\mathrm{Cu}$ contents extracted with the $\mathrm{HCl}$ solution and the quantity accumulated by maize plants $(0.74$; $\mathrm{p}<0.01)$ and soybean plants $(0.81 ; \mathrm{p}<0.01)$. These results differ from those found by Bataglia \& Raij (1989) in a study involving 26 soils from the state of São Paulo, who observed low efficiency of the $\mathrm{HCl}$ extractant in estimating the quantity of $\mathrm{Cu}$ for sorghum and sunflower crops, with correlation coefficients between the $\mathrm{Cu}$ content of the soil and the quantity accumulated by these crops of 0.47 for sorghum and 0.35 for sunflower. However, the authors did not indicate if this was due to a few soils with very different properties, or if dispersion of the points was normal, showing the incapability of the $\mathrm{HCl}$ solution in estimating $\mathrm{Cu}$ availability for the plants.

The correlation coefficients between the $\mathrm{Cu}$ content extracted with Mehlich-1 and the $\mathrm{Cu}$ quantity accumulated by the plants were $0.68(\mathrm{p}<0.01)$ and $0.77(\mathrm{p}<0.01)$ for the first and second plantings with wheat and bean, respectively (Figure 1b). A low degree of similarity was observed for the two crops, even with statistical significance for the coefficients (Figure 1b). The higher correlation coefficient for common bean than for wheat may indicate influence of the test plant species. Nevertheless, this conclusion cannot be supported because the removal of only one of the studied soils could change the magnitude of the coefficients.

Mehlich-1 had the lowest correlation coefficients between the $\mathrm{Cu}$ content in the soil and that accumulated by the plants, indicating that this method was the least effective in assessing $\mathrm{Cu}$ availability of PR soils for wheat and bean plants. Bortolon \& Gianello (2009) also observed the low efficiency of Mehlich-1 in assessing $\mathrm{Cu}$ availability for maize and for soybean in soils of the state of Rio
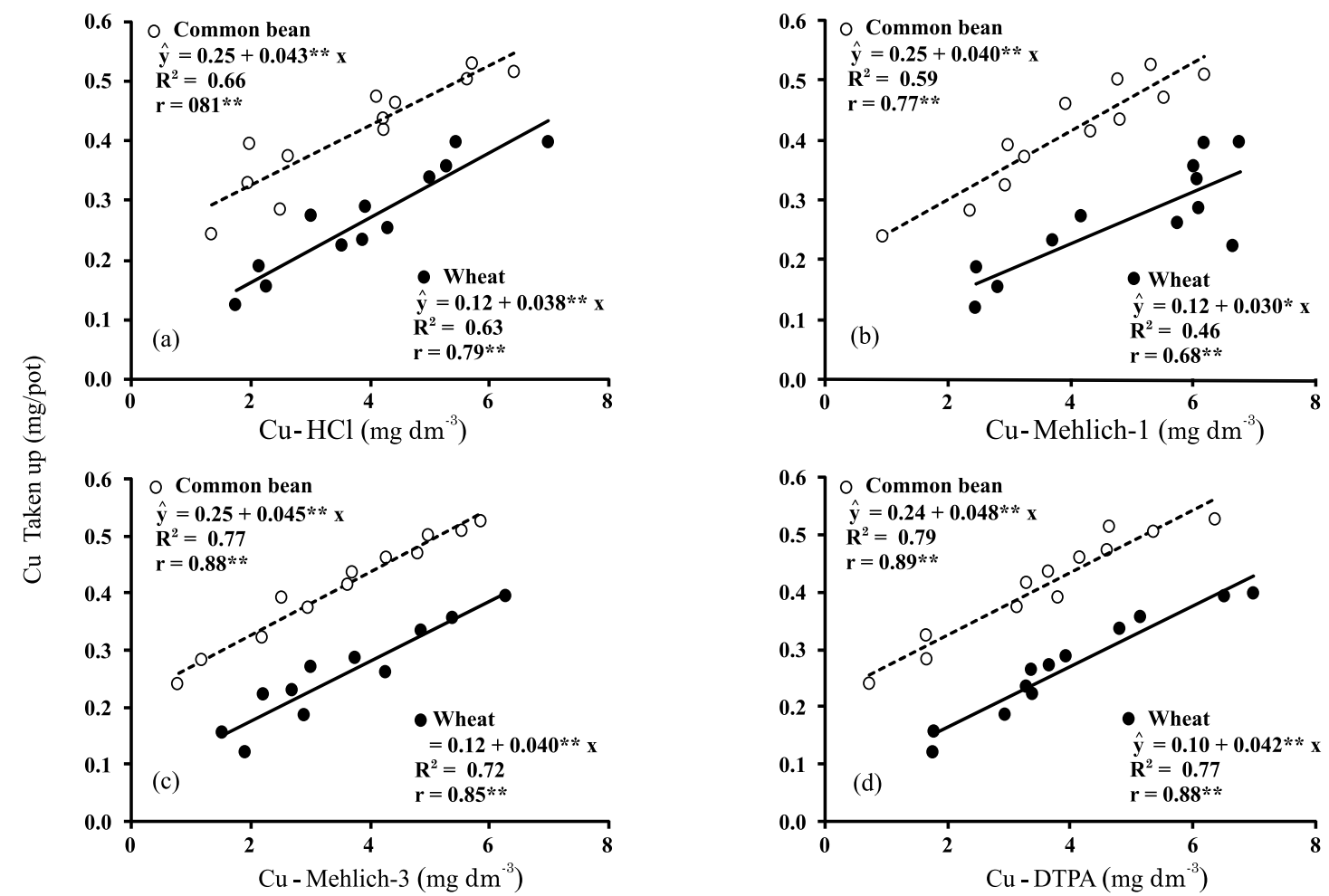

Figure 1. Relationship between the Cu contents extracted from the soil by $\mathrm{HCl}-(\mathrm{a})$, Mehlich-1 - (b), Mehlich$3-(c)$ and DTPA (d) and the quantity accumulated in wheat $(O)$ and common bean $(O)$ plants, in the first and second planting period, respectively. *: $p<0.05$. **: $p<0.01$. $(n=4)$. 
Grande do Sul. The coefficients obtained between the contents extracted with the Mehlich-1solution and the quantity accumulated by these crops were 0.59 $(p<0.05)$ for maize and $0.65(p<0.01)$ for soybean. In another study involving 26 soils from the state of São Paulo, Bataglia \& Raij (1989) assessed Cu availability with the test plants sunflower and sorghum and found even lower correlation coefficients $(r=0.36$ and $r=0.44$, respectively) than those reported by Bortolon \& Gianello (2009) and in the present study. Borkert et al. (2004), however, concluded that Mehlich-1 adequately assessed plant-available $\mathrm{Cu}$. Nevertheless, this may be due to the use of increasing $\mathrm{Cu}$ doses in one soil type only, which eliminates the variability among soils.

The relationship of the $\mathrm{Cu}$ content extracted from the soil by Mehlich-3 and $\mathrm{Cu}$ accumulated by plants is presented in figure 1c. The correlation coefficients were $0.85(p<0.01)$ and $0.88(p<0.01)$ for wheat and common bean, respectively. Similar correlation coefficients were obtained between the $\mathrm{Cu}$ content extracted from the soil with DTPA and $\mathrm{Cu}$ accumulated by the wheat and bean plants (Figure 1d). The correlation coefficients were $0.88(\mathrm{p}<0.01)$ and $0.89(\mathrm{p}<0.01)$ for wheat and common bean, respectively.

Silva et al. (2003) used the Mehlich-3 solution in a study for assessment of $\mathrm{Cu}$ availability in $\mathrm{PR}$ soils and obtained a coefficient of determination of 0.37 between the contents extracted by that solution and the quantity of $\mathrm{Cu}$ accumulated by maize plants. The soils used were sandy, with adjusted acidity and organic matter contents from 15 to $40 \mathrm{~g} \mathrm{dm}^{-3}$. When regression was made only with clayey soils, with organic matter contents ranging from 35 to $50 \mathrm{~g} \mathrm{dm}^{-3}$, these authors obtained a correlation coefficient of 0.84 . They verified that the soil type influenced the performance of the method. Borkert et al. (2004) also tested this extractant and concluded that Mehlich-3 is efficient to assess plant-available $\mathrm{Cu}$.

In general, the correlation coefficients between the $\mathrm{Cu}$ content in the soil and $\mathrm{Cu}$ accumulated by plants were higher with the chelating acid (Mehlich-3) and chelating extractants (DTPA) than with the acid extractants (HCl and Mehlich-1) (Figure 1). The superiority of Mehlich-3 and DTPA in assessing soil plant-available $\mathrm{Cu}$ may be explained by the presence of chelates (EDTA and DTPA), which have a high chelating capacity for this element. In a study to assess the efficiency of multiple element extractants in 31 soils of the state of São Paulo, Abreu et al. (1996) obtained a correlation coefficient of $0.89(p<0.01)$ for Mehlich-3 and concluded that the extractants with chelating agents are more efficient to assess soil plantavailable Cu. However, Cruz \& Ferreira (1990) utilized acid extractants, salts and chelating agents for soils from Jaboticabal (SP) and concluded that all but $0.5 \mathrm{~mol} \mathrm{~L}^{-1} \mathrm{CaCl} 2$ had significant and similar correlation coefficients between the $\mathrm{Cu}$ content extracted from the soil and that accumulated by maize. Likewise, Borkert et al. (2004) and Silva et al. (2009) detected no difference between the Mehlich3 and Mehlich- 1 extractants to assess $\mathrm{Cu}$ availability for soybean and for maize, respectively, concluding that both extractants may be used. Due to operational ease in the laboratory, Mehlich-1 would be more indicated since this method also allows $\mathrm{P}$ and $\mathrm{K}$ determination.

The highest $\mathrm{Cu}$ contents were extracted by Mehlich-1 and the lowest by DTPA and Mehlich-3 (Figure 1). These results confirmed Silva et al. (2009), who reported highest $\mathrm{Cu}$ contents in $\mathrm{PR}$ soils by Mehlich1 and lowest contents by DTPA. However, Borges \& Coutinho (2004) verified that DTPA extracted more $\mathrm{Cu}$ than Mehlich-1 and Mehlich-3, regardless of liming. Sims et al. (1989), in turn, studied 400 soil samples from Delaware and showed that Mehlich-3 extracted $50 \%$ more $\mathrm{Cu}$ than Mehlich-1.

\section{Zn content in the soil and accumulated in plants}

The relationship between the $\mathrm{Zn}$ content extracted from the soil with $\mathrm{HCl}$ and the $\mathrm{Zn}$ quantity accumulated in the plants is shown in figure $2 \mathrm{a}$. The correlation coefficients were $0.77(\mathrm{p}<0.01)$ and 0.75 $(\mathrm{p}<0.01)$ for wheat and common bean, respectively. In 26 soils from the state of São Paulo, Bataglia \& Raij (1989) obtained a correlation coefficient of 0.74 for the same comparison with sunflower. Contrary results were reported by Bortolon \& Gianello (2009) in a study of 12 soils from the state of Rio Grande do Sul, where the efficiency of $\mathrm{HCl}$ in estimating $\mathrm{Zn}$ availability for maize and soybean was low, with correlation coefficients between the soil content and the quantity accumulated by these crops was 0.42 and 0.60 , respectively.

Similar correlation coefficients between the $\mathrm{Zn}$ content extracted from the soil with $0.1 \mathrm{~mol} \mathrm{~L}^{-1} \mathrm{HCl}$ and the $\mathrm{Zn}$ quantity accumulated in wheat and bean plants were obtained for the extractants Mehlich-1 (Figure 2b) and Mehlich-3 (Figure 2c). These results indicate that the acid extractants ( $\mathrm{HCl}$ and Mehlich-1) and chelating acid (Mehlich-3) were equivalent in assessing $\mathrm{Zn}$ availability in PR soils for wheat and bean. In a study of 18 soils from the state of Paraná, Silva et al. (2009) also reported the similarity of Mehlich-1, Mehlich-3 and DTPA in estimating the plant available soil content of $\mathrm{Zn}$.

In diverse comparison studies of extraction methods, Mehlich-1 was not efficient in assessing soil $\mathrm{Zn}$ plant availability. In the studies of Bataglia \& Raij (1989) and Bataglia \& Raij (1994), correlation coefficients varied from 0.46 to 0.52 for sorghum and maize, respectively. In a study by Bortolon \& Gianello (2009), correlation coefficients of 0.56 and 0.60 were obtained for maize and soybean, respectively. In this study, the efficiency of $\mathrm{HCl}$, Mehlich-1 and Mehlich-3 to assess Zn plant availability was medium $(\mathrm{r}<0.80)$; 
however, the Mehlich-1 solution was more advantageous due to ease of operation in laboratories for routine soil analyses, because this method also allows $\mathrm{P}$ and $\mathrm{K}$ determination.

The correlation coefficients between the Zn content extracted from the soil with DTPA and the quantity accumulated in plants were $0.90(\mathrm{p}<0.01)$ for wheat and $0.88(p<0.01)$ for bean (Figure $2 d)$. A low degree of similarity between the two crops was observed by the angular coefficients of the regression lines, even with similar correlation coefficients (Figure 2d). This evidence may indicate the influence of the plant species used, as well as other factors (e.g, reaction of the element in the soil and to climatic conditions) that change over time, in other words, from one growing season to another.

Of all extractants, DTPA estimated the soil Zn fraction available for wheat and bean best (Figure $2 \mathrm{~d}$ ). The greater correlation coefficients obtained with DTPA may be attributed to the fact that this solution preferentially extracts the $\mathrm{Zn}$ bonded to organic matter and does not solubilize other Zn forms in the soil, e..g, acid extractants. Abreu \& Raij (1996) also found the highest coefficients $(r=0.84 ; p<0.01)$ between the $\mathrm{Zn}$ content extracted with DTPA and the quantity accumulated by maize plants in comparison with Mehlich-1 $(r=0.61 ; p<0.01)$. Similar results were found by Singh \& Sekhon (1991) and Abreu et al. (1997), who attributed the best efficiency in $\mathrm{Zn}$

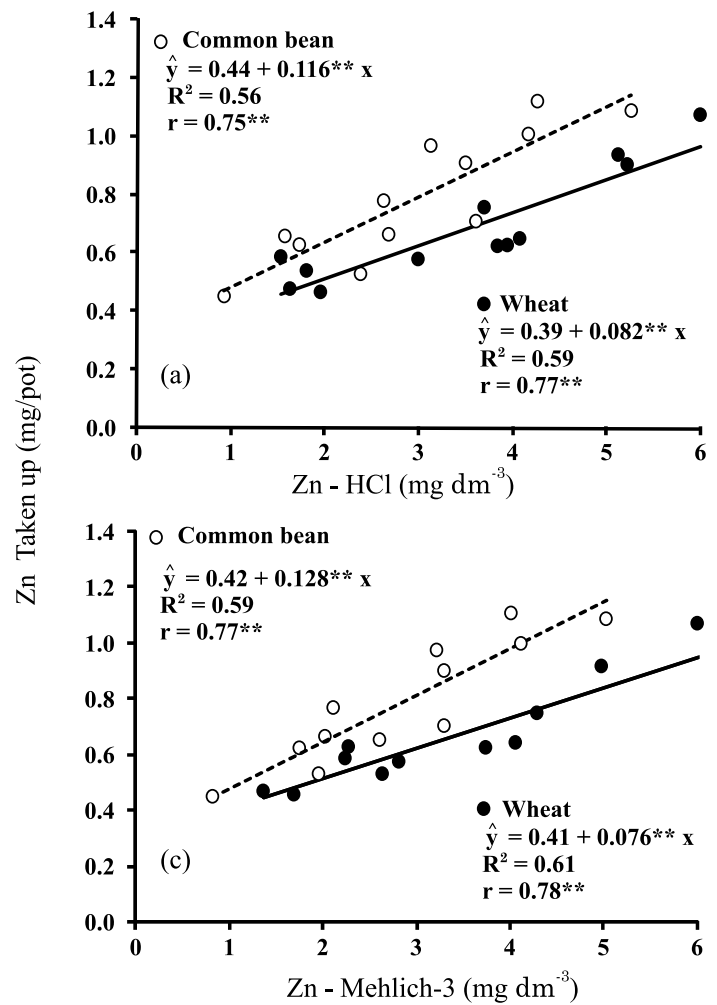

extraction to DTPA. These results, however, differ from those reported by Gonçalves Júnior et al. (2006), who found a greater correlation coefficient between the $\mathrm{Zn}$ contents in clayey soil of Paraná and the quantity accumulated by maize when using Mehlich1 than by DTPA. Silva et al. (2003) however reported higher coefficients $(r=0.75 ; \mathrm{p}<0.01)$ between the $\mathrm{Zn}$ quantity accumulated by soybean in the studied soils contents extracted with Mehlich-3 than with Mehlich-1 and DTPA.

The highest $\mathrm{Zn}$ contents were extracted from the soils occurred using $\mathrm{HCl}$ and Mehlich-1 (Figure 2a,b). A higher $\mathrm{Zn}$ content by acid than by chelating extractants was also verified by Abreu \& Raij (1996), Pereira et al. (2001), Borges \& Coutinho (2004), Araújo $\&$ Nascimento (2005), Ortiz et al. (2007) and Silva et al. (2009), the latter two studies focused on soils from the state of Paraná. The greater capacity of the acid agents to extract soil $\mathrm{Zn}$ may be attributed to solubilization of $\mathrm{Zn}$ forms in the soil, a fact that does not occur with DTPA since it extracts only the most soluble compounds in buffered pH (Motta et al., 2007).

\section{Fe content in the soil and accumulated in plants}

The correlation coefficients between the $\mathrm{Fe}$ extracted from soil with $0.1 \mathrm{~mol} \mathrm{~L}^{-1} \mathrm{HCl}$ and $\mathrm{Fe}$ accumulation by plants were $0.65(\mathrm{p}<0.01)$ for wheat and $0.79(\mathrm{p}<0.01)$ for soybean (Figure $3 \mathrm{a})$. For Mehlich-1, the relationship between Fe extracted from
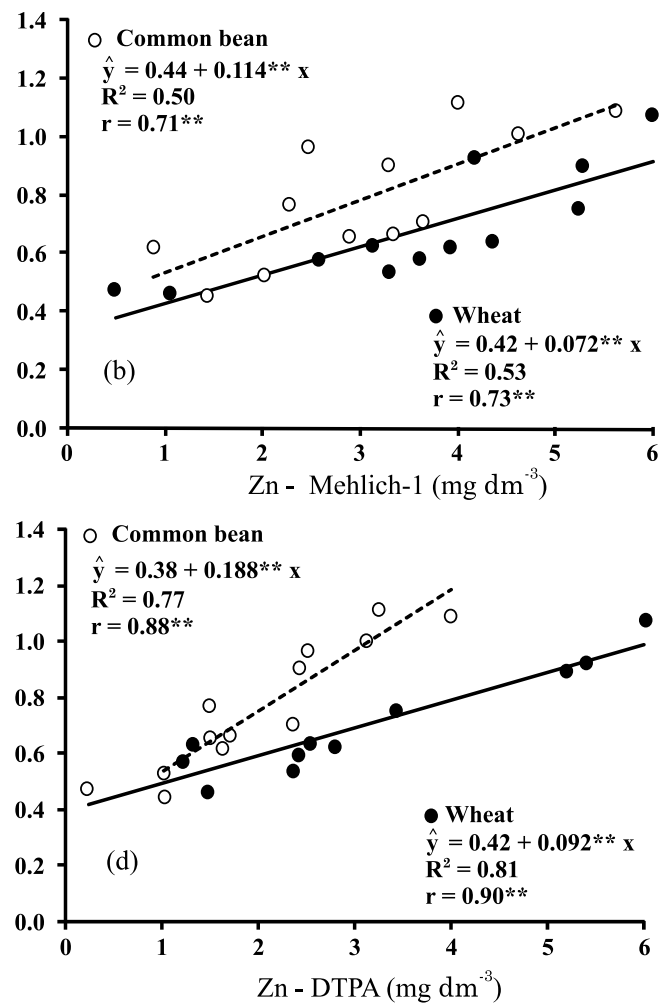

Figure 2. Relationship between the Zn contents extracted from the soil by HCl- (a), Mehlich-1 - (b), Mehlich3 - (c) and DTPA (d) and the quantity accumulated in wheat $(O)$ and common bean $(O)$ plants, in the first and second planting period, respectively. *: $p<0.05 . * *: p<0.01 .(n=4)$. 
soil and Fe accumulated in plants is shown in figure $3 \mathrm{~b}$. The correlation coefficients were $0.58(p<0.05)$ for wheat and $0.81(p<0.01)$ for common bean.

The dispersion of the points obtained in this study for Fe extraction with HCl, Mehlich-1 and Mehlich-3 may be attributed to high variability in the physical, chemical and mineralogical properties of the studied soils. In addition, a low degree of similarity between the two tested crops was observed, even with statistical significance for the coefficients (Figure 3a,b,c). The higher correlation coefficient for common bean than for wheat may indicate influence of the test plant species. Nevertheless, this conclusion cannot be supported because the removal of only one of the studied soils could change the magnitude of the coefficients.

The low relationship between Fe accumulated by the plants and the Fe contents extracted by Mehlich3 shows that the method was not efficient in assessing Fe availability for wheat and bean in PR soils with wide variations in chemical, physical and mineralogical properties (Figure 3c). The correlation coefficients were $0.45(\mathrm{p}<0.05)$ for wheat and 0.61 $(p<0.01)$ for soybean (Figure 3c). In a study on the efficiency of micronutrient extractants from 18 PR soils, the correlation coefficients found by Silva et al. (2004) were even lower $(r=0.28 ; p<0.05)$ than in this study, for the same relationship.

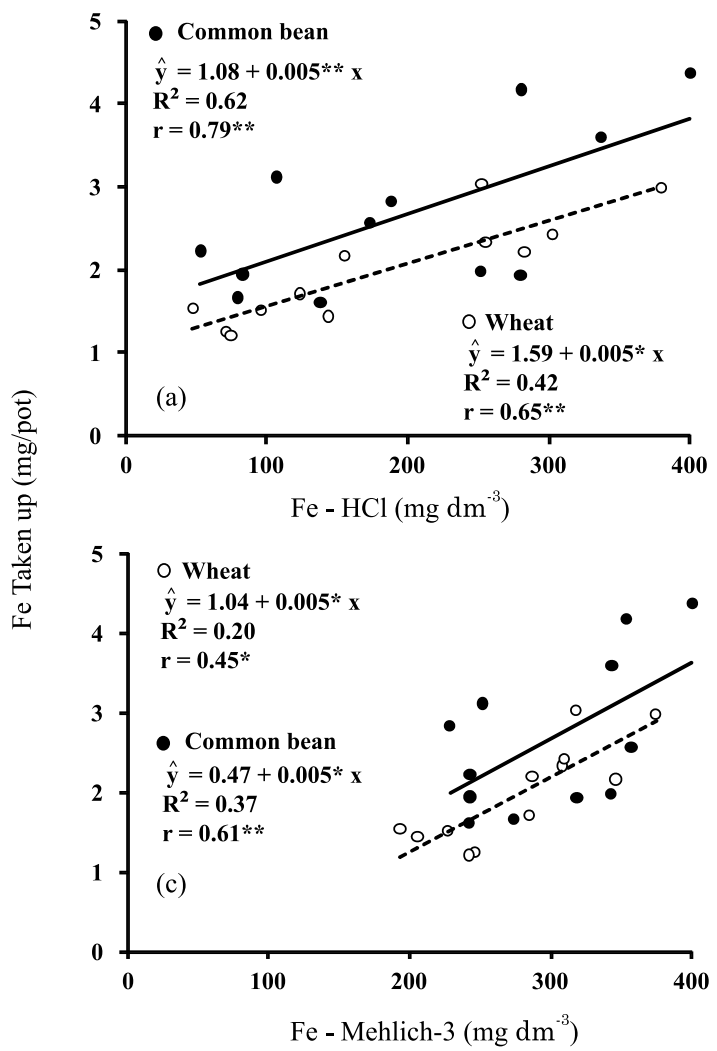

The correlation coefficients between the Fe extracted from soil with DTPA and the quantity of Fe accumulated by the plants were $0.81(p<0.01)$ for wheat and $0.82(p<0.01)$ for the soybean (Figure $3 d)$. This confirms data obtained by Abreu et al. (1997), who attributed the best Fe extraction efficiency from the soil to DTPA. However, Bataglia \& Raij (1989) found no significant correlation for Fe with the use of the acid extractant (Mehlich-1) and chelating extractant (DTPA) in a sunflower - sorghum crop.

The soil Fe contents were highest by the extractant Mehlich-3 (Figure 3). A greater soil extraction capacity of Fe with Mehlich-3 was reported in other studies performed by Rodrigues et al. (2001) in soils from the Amazon region and by Silva et al. (2004) and Fonseca et al. (2010) in soils from Paraná. DTPA, on the other hand, extracted the lowest Fe quantities from the soil (Figure 3), corroborating the results of Abreu et al. (1997), Silva et al. (2004, 2009) and Pigozzo et al. (2008).

\section{Mn content in the soil and accumulated in plants}

The relatioship between the Mn content extracted from the soil with the different extractants and Mn accumulated by plants is shown in figure 4 . Regardless of the extractant, the correlation coefficients were similar, ranging from 0.70 to 0.79 for wheat and from 0.80 to 0.89 for bean. These data
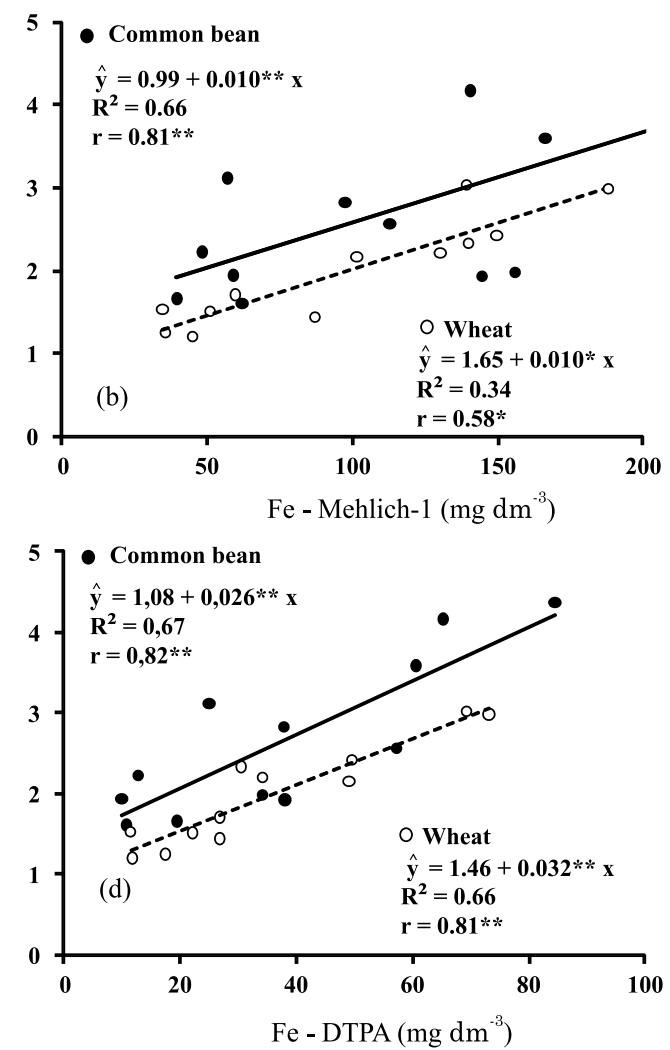

Figure 3. Relationship between the Fe contents extracted from the soil by HCl-(a), Mehlich-1 - (b), Mehlich3 - (c) and DTPA (d) and the quantity accumulated in wheat $(O)$ and common bean (O) plants, in the first and second planting period, respectively.*: $p<0.05$. $* *$ : $<<0.01 .(n=4)$. 

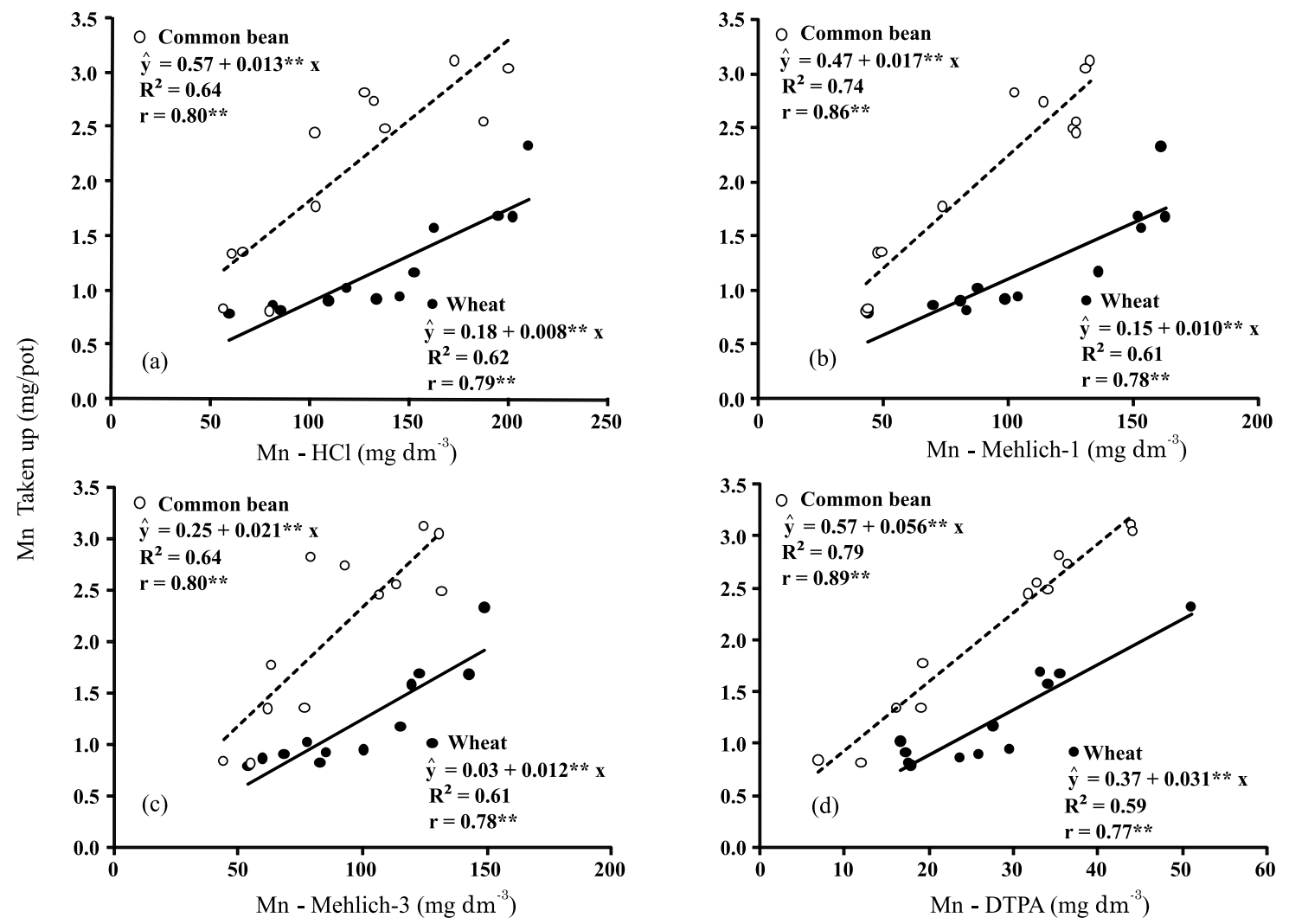

Figure 4. Relationship between the Mn contents extracted from the soil by HCl- (a), Mehlich-1 - (b), Mehlich3 - (c) and DTPA (d) and the quantity accumulated wheat $(0)$ and common bean $(O)$ plants, in the first and second planting period, respectively. *: $\mathrm{p}<0.05$. **: $\mathrm{p}<0.01$. $(\mathrm{n}=4)$.

show that the efficiency of all tested extractants was similar in assessing Mn plant availability in PR soils with wide variations in chemical, physical and mineralogical properties. The angular coefficients of the regression lines showed a low degree of similarity between the two crops, in spite of similar correlation coefficients (Figure 4). This may indicate an influence of the plant species used, as well as other factors (e.g, reaction of the element in the soil and to climatic conditions) that change over time, in other words, from one growing season to another.

In maize, Abreu et al. (2004) found a greater correlation for Mn extraction when using DTPA and resin. Correlations between Mehlich-1 and Mehlich3 were similar. Ortiz et al. (2007) found a correlation of 0.88 ( $p<0.01)$ between Mn extracted by DTPA and Mehlich-1 in PR soils. The results differ from those in other soils and climatic conditions, as those described by Rodrigues et al. (2001) and Bataglia \& Raij (1989), indicating DTPA as more suitable for Mn extraction than Mehlich-1. Oliveira \& Nascimento (2006) suggested Mehlich-1 and DTPA as the extractants with the best correlations with plantavailable Mn forms in soils of the state of Pernambuco.

$\mathrm{Mn}$ contents were highest when extracted by $\mathrm{HCl}$ (Figure 4a). This confirms the finding of Pereira et al. (2001), who reported that the Mn extraction capacity of $0.1 \mathrm{~mol} \mathrm{~L}{ }^{-1} \mathrm{HCl}$ was greater than of DTPA and Mehlich-1. DTPA extracted the lowest Mn quantities from the soils.

\section{CONCLUSIONS}

1. The efficiency of the extractants $\mathrm{HCl}$, Mehlich3 and DTPA to assess $\mathrm{Cu}$ plant availability was similar, while Mehlich-1 proved less efficient for this purpose in the soils studied.

2. The $0.1 \mathrm{~mol} \mathrm{~L}^{-1} \mathrm{HCl}$, Mehlich-1 and Mehlich-3 were less efficient as estimators of $\mathrm{Zn}$ and Fe plant availability, and DTPA is indicated as the best-suited extractant.

3. The efficiency of the extractants $\mathrm{HCl}$, Mehlich-1, Mehlich-3 and DTPA to assess Mn plant availability was similar.

\section{LITERATURE CITED}

ABREU, C.A.; RAIJ, B.van; ABREU, M.F.; SANTOS, W.R. \& ANDRADE, J.C. Efficiency of multinutrient extractants for the determination of available copper in soils. Comm. Soil Sci. Plant Anal., 27:763-771, 1996. 
ABREU, C.A.; RAIJ, B.van; ABREU, M.F. \& PAZ GONZALEZ, A. Avaliação da disponibilidade de manganês e ferro em solos pelo uso do método modificado da resina de troca aniônica. R. Bras. Ci. Solo, 28:579-584, 2004.

ABREU, C.A.; ABREU, M.F.; SOARES, L.H. \& ANDRADE, J.C. The effects of the DTPA extraction conditions on the determination of micronutrients in Brazilian soils. Comm. Soil Sci. Plant Anal., 28:1-11, 1997.

ABREU, C.A. \& RAIJ, B.van. Efeito da reação do solo no zinco extraído pelas soluções de DTPA e Mehlich-1. Bragantia, 55:357-363, 1996.

ARAÚJO, J.C.T. \& NASCIMENTO, C.W.A. Fracionamento e disponibilidade de zinco por diferentes extratores em solos incubados com lodo de esgoto. R. Bras. Ci. Solo, 29:97795, 2005.

BATAGLIA, O. \& RAIJ, B.van. Eficiência de extratores de micronutrientes na análise de solo. R. Bras. Ci. Solo, 13:205-212, 1989.

BATAGLIA, O. \& RAIJ, B.van. Soluções extratoras na avaliação da fitodisponibilidade de zinco em solos. R. Bras. Ci. Solo, 18:454-461, 1994.

BORGES, M.R. \& COUTINHO, E.L.M. Metais pesados do solo após a aplicação de biossólido: II. Disponibilidade. R. Bras. Ci. Solo, 28:557-568, 2004.

BORKERT, C.M.; SFREDO, G.J; ORTIZ, F.R. \& BRITO, O.R Extratores para zinco, cobre e manganês em Latossolo Vermelho distrófico. In: REUNIÃO DA PESQUISA DE SOJA DA REGIÃO SUL, 32., Passo Fundo, 2004. Resumos... Passo Fundo, Embrapa Trigo, 2004. p.70-71.

BORTOLON, L. \& GIANELLO, C. Disponibilidade de cobre e zinco em solos do Sul do Brasil. R. Bras. Ci. Solo, 33:647. 658, 2009 .

BÜLL, L.T. \& BERTANI, R.M.A. Métodos de análise química de solo para fins de fertilidade. Botucatu, UNESP/FCA, 2001. $62 \mathrm{p}$

CRUZ, M.C.P. \& FERREIRA, M.E. Seleção de métodos para a avaliação do cobre disponível nos solos. Pesq. Agropec. Bras., 25:647-659, 1990

EMPRESA BRASILEIRA DE PESQUISA AGROPECUÁRIA EMBRAPA. Centro Nacional de Pesquisa de Solos. Manual de métodos e análises de solos. 2.ed. Rio de Janeiro, 1997. 212p.

EMPRESA BRASILEIRA DE PESQUISA AGROPECUÁRIA EMBRAPA. Centro Nacional de Pesquisa de Solos. Sistema brasileiro de classificação de solos. 2.ed. Brasília, 2006. 306p.

FERREIRA, M.E. \& CRUZ, M.C.P. Seleção de extratores químicos para avaliação da disponibilidade de zinco em solos do estado de São Paulo. Pesq. Agropec. Bras., 27:293 304, 1992.

FONSECA, A.F.; CAIRES, E.F. \& BARTH, G. Extraction methods and availability of micronutrients for wheat under a no-till system with a surface application of lime. Sci. Agric., 67:60-70, 2010.
GONÇALVES JÚNIOR, A.C.; PRESTES A.L.; TRAUTMANN, R.R.; SANTOS, A.L. \& ANDREOTTI, M. Avaliação de extratores e fitodisponibilidade de zinco para a cultura do milho em Latossolo Vermelho eutroférrico. Acta Sci. Agron., 28:7-12, 2006.

LINDSAY, W.L. \& NORVELL, W.A. Development of a DTPA soil test for zinc, iron, manganese and copper. Soil Sci. Soc. Am. J., 42:421-427, 1978.

LOPES, S.D. \& ABREU, C.A. Micronutrientes na agricultura brasileira: Evolução histórica e futura. In: NOVAIS, R.F.; ALVAREZ V., V.H. \& SCHAEFER, C.E.G.R., eds. Tópicos em ciência do solo. Viçosa, MG, Sociedade Brasileira em Ciência do Solo, 2000. p.265-298.

MALAVOLTA, E.; VITTI, G.C. \& OLIVEIRA, S.A. Avaliação do estado nutricional das plantas: Princípios e aplicações. 2.ed. Piracicaba, Potafós, 1997.

MEHLICH, A. Determination of $\mathrm{P}, \mathrm{Ca}, \mathrm{Mg}, \mathrm{K}, \mathrm{Na}$ and $\mathrm{NH} 4$ by North Carolina Soil Testing Laboratories. Raleigh, University of North Carolina, 1953.

MENEZES, A.A.; DIAS, L.E.; NEVES, J.C.L. \& SILVA, J.V.O. Disponibilidade de zinco para milho pelos extratores Mehlich-1, Mehlich-3 e DPTA em solos de Minas Gerais, na presença e ausência de calagem. R. Bras. Ci. Solo, $34: 417-424,2010$.

MOTTA, A.C.V.; SERRAT, B.M.; REISSMANN, C.B. \& DIONÍSIO, J.A., eds. Micronutrientes na rocha, no solo e na planta. Curitiba, Universidade Federal do Paraná, 2007. $246 \mathrm{p}$.

MURAOKA, T.; NEPTUNE, A.M.L. \& NASCIMENTO FILHO, V.F. Avaliação da disponibilidade de zinco e de manganês do solo para o feijoeiro. I. Zinco. R. Bras. Ci. Solo, 7:167$175,1983$.

OLIVEIRA, A.B. \& NASCIMENTO, C.W.A. Formas de manganês e ferro em solos de referência de Pernambuco. R. Bras. Ci. Solo, 30:99-110, 2006.

ORTIZ, F.R.; BRITO, O.R. \& BORKERT, C.M. Extratores para a quantificação de zinco, cobre e manganês em solo arenoso. Sci. Agr., 8:95-98, 2007.

PEREIRA, M.G.; PÉREZ, D.V.; VALLADARES, G.S.; SOUZA, J.M.P.F. \& ANJOS, L.H.C. Comparação de métodos de extração de cobre, zinco, ferro e manganês em solos do estado do Rio de Janeiro. R. Bras. Ci. Solo, 25:655-660, 2001.

PIGOZZO, A.T.J.; LENZI, E.; LUCA JÚNIOR, J.; SCAPIM, C.A.; VIDIGAL FILHO, P.S. \& COSTA, A.C.S. Reação do solo e disponibilidade de micronutrientes, em solo de textura média tratado com lodo de esgoto e cultivado com milho. Acta Sci. Agron., 30:569-579, 2008.

RAIJ, B.van; CANTARELLA, H.; QUAGGIO, J.A. \& FURLANI, A.M.C. Recomendação de adubação e calagem para o estado de São Paulo. 2.ed. Campinas, Instituto Agronomico de Campinas, 1997. (Boletim Técnico, 100)

RODRIGUES, M.R.L.; MALAVOLTA, E. \& MOREIRA, A. Comparação de soluções extratoras de ferro e manganês em solos da Amazônia. Pesq. Agropec. Bras., 36:143-149, 2001. 
SILVA, M.A.G.; MUNIZ, A.S.; MATA, J.D.V. \& CEGANA, A.C.V. Extratores para a quantificação do zinco e do cobre em solos cultivados com soja. Acta Sci. Agron., 26:361-366, 2003.

SILVA, M.A.G.; MUNIZ, A.S.; NODA, A.Y.; MARCHETTI, M.E.; MATA, J.D.V. \& LOURENTE, E.R.P. Metodologias e eficiência de extratores para zinco, cobre, ferro e manganês. Acta Sci. Agron., 31:537-545, 2009.

SILVA, M.A.G.; MUNIZ, A.S.; COSTA, A.C.S. \& CEGANA, A.C.V. Extratores para a quantificação de $\mathrm{Fe}$ em solos cultivados com soja. Acta Sci. Agron., 26:367-371, 2004.

SIMS, J.T. Comparisons of Mehlich I and Mehlich III extractants for $\mathrm{P}, \mathrm{K}, \mathrm{Ca}, \mathrm{Mg}, \mathrm{Mn}, \mathrm{Cu}$ and $\mathrm{Zn}$ in Atlantic coastal plain soils. Comm. Soil Sci. Plant Anal., 20:17071726,1989
SINGH, M. \& SEKHON, G.S. DTPA extractable micronutrient cations in twenty soil series of India. J. Indian Soc. Soil Sci., 39:129-133, 1991.

TEDESCO, M.J.; GIANELLO, C.; BISSANI, C.A.; BOHNEN, H. \& VOLKWEISS, S.J. Análises de solos, plantas e outros materiais. 2.ed. Porto Alegre, Universidade Federal do Rio Grande do Sul, 1995. 174p. (Boletim Técnico, 5)

WEAR, J.I. \& SOMMER, A.L. Acid extractable zinc of soils in relation to the occurrence of zinc deficiency symptoms of corn: A method of analysis. Soil Sci. Soc. Am. Proc., 12:143144. 1948. 
